\title{
Õpetajate küberkiusamine ja võimalikud sekkumised koolis: õpilastepoolset küberkiusamist kogenud õpetajate vaade
}

\author{
Kätlyn Jürisaara ${ }^{a}$, Andra Siibak ${ }^{\mathrm{a}}$ \\ ${ }^{a}$ Tartu Ülikooli ühiskonnateaduste instituut
}

\begin{abstract}
Annotatsioon
Artikli eesmärk on analüüsida õpilastepoolset küberkiusamist kogenud Eesti üldhariduskooli õpetajate $(\mathrm{N}=14)$ arvamusi ja kogemusi ning uurida, milliseid koolipoolseid sekkumisvõimalusi õpetajad selliste küberkiusamise juhtumite lahendamiseks näevad. Poolstruktureeritud individuaalintervjuu meetodil otsiti vastuseid järgmistele uurimisküsimustele: 1) milliste õpilastepoolsete küberkiusamise liikidega on õpetajad kokku puutunud; 2) kuidas võiks kool õpetajate küberkiusamisjuhtumitesse sekkuda. Intervjueeritud õpetajad olid peamiselt kokku puutunud viie küberkiusamise liigiga: 1) töödeldud fotod;2) kirjad ja sõnumid; 3) laim ja valeinfo jagamine; 4) jälitamine ja ahistamine veebis; 5) kellegi teise nime all esinemine. Küberkiusamist kogenud õpetaja turvatunde loomise ja juhtumi efektiivse lahendamise eesmärgil peeti oluliseks õpetajate küberkiusamist taunivate meetmete sätestamist kooli regulatsioonides, toetavate juhendmaterjalide loomist, koolipere harimist küberkiusamise vallas ning psühholoogilise ja tehnilise nõustamise tagamist.
\end{abstract}

Võtmesõnad: küberkiusamine, õpetajate küberkiusamine, elektrooniline kiusamine, kool, sekkumise meetmed, õpilased

\section{Sissejuhatus}

Avatud suhtlemisel ja eneseavamisel on õpetajate ja õpilaste omavahelises suhtluses oluline roll (Žardeckaitė-Matulaitienė \& Paluckaitė, 2013). Varem peamiselt füüsilises kooli- ja klassiruumis toimunud suhtlus on praeguseks kolinud ka internetti, sealhulgas sotsiaalmeedia avarustesse (Gunnulfsen, 2016). Uuringutest nähtub, et õpilaste ja õpetajate sotsiaalmeedia interaktsioon annab olulise panuse vahetu ja avatud suhtlemise tekkele, aidates muu hulgas parandada

Ühiskonnateaduste instituut, Tartu Ülikool, Lossi 36, 51003 Tartu;

katlyn.jyrisaar@gmail.com. 
nii üldist suhtluskliimat klassiruumis kui ka õpilaste õpimotivatsiooni ning -tulemusi (Asterhan \& Rosenberg, 2015; Keasberry, 2018).

Ometi võib sellisel digitehnoloogia vahendatud suhtlusel olla ka varjukülg, kuna tehnoloogia ja informatsiooni väärkasutamise tulemusena võivad õpetajad langeda õpilaste poolt küberkiusamise ohvriks (Kyriacou \& Zuin, 2016). Küberkiusamine on Smithi jt (2008) uurijate kohaselt ühele või mitmele inimesele suunatud agressiivne ja tahtlik tegu, mis pannakse toime elektrooniliste vahendite (nt e-posti, tekstisõnumite, sotsiaalmeedia platvormide või jututubade) kaudu korduvalt ja pikema aja jooksul. Küberkiusaja võib olla nii üksikisik kui ka rühm ning see on suunatud ohvri vastu, kes ei saa end kergesti kaitsta (ibid.).

Rahvusvahelistest uuringutest (Kopecký \& Szotkowski, 2017a; NASUWT, 2013; Phippen, 2011) nähtub, et küberkiusamisega, peamiselt just õpilas(t)e poolt, on kokku puutunud arvestatav hulk õpetajatest. Olgugi et küberkiusamise probleemi tõsidusele on tähelepanu juhtinud mitu autorit (Eden, Heiman, \& Olenik-Shemesh, 2013, lk 1040; Kyriacou \& Zuin, 2016, lk 259) ning ka küberkiusamisega kaasneda võivate tagajärgede valulikkust on uuringutes (Davenport, 2014; Kopecký \& Szotkowski, 2017b; NASUWT, 2013) esile toodud, leidub endiselt üsna vähe empiirilisi uuringuid, mis oleks õpetajate küberkiusamise teema fookusesse võtnud. Ilmunud uuringud on peamiselt kvantitatiivsed (vt Kopecký \& Szotkowski, 2017a; NASUWT, 2013; Ontario College of Teachers, 2007; Phippen, 2011), seevastu kvalitatiivseid uuringuid, mis aitaksid vahetult avada õpetajate kogemuste sisu ja olemust, on teaduskirjanduses ilmunud veel napilt (Kyriacou \& Zuin, 2016).

Kuigi ka mitmes Eesti üliõpilastöös (Paal, 2014; Saveljev, 2017; Sule, 2019; Tikk, 2017; Välimaa, 2016) on viiteid õpetajate küberkiusamisele õpilaste poolt, ei ole konkreetse fookusega uuringuid Eestis siiani tehtud. Siinse artikli eesmärk on seda tühimikku täita, analüüsides õpilastepoolset küberkiusamist kogenud Eesti üldhariduskooli ópetajate $(\mathrm{N}=14)$ arvamusi ja kogemusi ning uurida, milliseid koolipoolseid sekkumisvõimalusi õpetajad selliste küberkiusamise juhtumite lahendamiseks näevad. Olgugi et küberkiusamise juhtumid on digivahendite poolt vahendatud ja tekitavad anonüümsuse tõttu sageli küsimusi kiusaja isikus (Nocentini et al., 2010), kuuluvad siinse uuringu valimisse õpetajad, kes olid enda küberkiusajatena identifitseerinud konkreetse(d) õpilase(d). Õpilas(t)epoolse küberkiusamise all mõistetakse siinses artiklis olukorda, kus ühe või mitme õpilase poolt veebiplatvormil tehtavat või elektrooniliste vahendite kaudu toimuvat tegevust (nt solvavaid kommentaare ja laimu levitamist, õpetaja fotode töötlemist ja loata jagamist, naeruvääristavate sõnumite saatmist, ähvardusi) tajub uuringus osalev õpetaja kui tema vastu suunatud küberkiusamist. 
Toetudes 2019. aasta kevadel tehtud intervjuudele õpilastepoolset küberkiusamist kogenud Eesti üldhariduskooli õpetajatega $(\mathrm{N}=14)$, saavad artiklis vastuse järgmised kaks uurimisküsimust: 1) milliste õpilastepoolsete küberkiusamise liikidega on õpetajad kokku puutunud ning 2) kuidas võiks kool õpetajate küberkiusamisjuhtumitesse sekkuda.

\section{Teoreetiline ülevaade}

\section{Küberkiusamise olemus ja liigid}

Sarnaselt (tava)kiusamisega peetakse küberkiusamise juures oluliseks teo tahtlikkust, ajalist korduvust ja võimu tasakaalutust (Smith et al., 2008). Samas on nende kriteeriumide rakendamine küberkiusamisele küllaltki keeruline ning tekitanud uurijate seas erinevaid seisukohti (Nocentini et al., 2010, lk 131-132).

Erinevalt nn tavakiusamisest on küberkiusamise puhul raskendatud tahtlikkuse hindamine, sest on keeruline hinnata, kas teo toimepanija eesmärgid olid pahatahtlikud või võis tegu olla ebaõnnestunud naljaga, mida ohver tõlgendab kiusamisena. Muu hulgas on Marwick ja boyd (2014) täheldanud märkimisväärseid erinevusi noorte ja täiskasvanute küberkiusamise tõlgendustes. Näiteks hindavad noored tõsisemaks küberkiusamist, mis on teostatud visuaalide (fotod, videod) ja veebis kellegi teisena esinemise (impersonation) teel, seevastu kirjalik-verbaalset küberkiusamist ja tõrjumist hinnati vähem tõsiseks (Naruskov, 2020).

Tõlgenduste keerukuse tingib ka tõik, et küberkeskkonnas ja tehnoloogiliste vahendite kaudu on raske hinnata kiusaja teo juures emotsioone ja hääletooni, mis vahetu kiusamise puhul annavad selgeid signaale tegelikest eesmärkidest (Rao, Bansal, \& Chandran, 2018; Vaillancourt, Faris, \& Mishna, 2017, lk 369). Ka kiusaja ise ei pruugi olla teadlik oma tegude tõsidusest (Menesini \& Nocentini, 2009, lk 230) ning küberkiusamine võib juhtuda kogemata, ilma et tegelikult soovitaks kellelegi liiga teha (Rao et al., 2018, lk 3). Kuna internetis on võimalik sinna laetud materjali korduvalt jagada ning pidevalt vaadata, isegi kui kiusaja võis materjali üles laadida vaid ühe korra (Vaillancourt et al., 2017, lk 369), on ka teo korduvuse määratlemine küberkiusamise puhul keeruline. Ühe küberkiusamise juhtumi puhul võib seetõttu ohvriks langeda justkui mitu korda (Bauman, 2014, lk 27). Samuti võib küberkiusamise eripäraks pidada tõika, et kui (tava)kiusamine sisaldab üldjuhul juba olemasolevat võimu tasakaalutust, siis tehnoloogia võib muuta võimusuhete olukorda, mistõttu ei pruugi tasakaalutus võimusuhetes igas küberkiusamise juhtumis eksisteerida. Võimu tasakaalutus võib küberkiusamisel tuleneda näiteks sotsiaalsest staatusest (nt teiste suur toetus internetikeskkonnas), anonüümsusest 
ja tehnoloogilise oskusteabe erinevustest ohvri ja kiusaja vahel (Menesini \& Nocentini, 2009, lk 230; Vaillancourt et al., 2017, lk 36).

Peale tavakiusamisele omaste tunnusjoonte on küberkiusamise puhul määravaks kriteeriumiks peetud veebikeskkondadele omaseid karakteristikuid - anonüümsust (anonymity), st ohver ei tea, kes on kiusaja, ning avalikkust (publicity), sest internetis toimuva küberkiusamise korral on kiusamisjuhtumisse kaasatud suurem auditoorium (Nocentini et al., 2010, lk 131). Erinevalt kiusamisest väljub küberkiusamine nn füüsiliste piiride raamidest, see tähendab, et kiusajal on võimalus kedagi kiusata ajalistest ja keskkonnaga seotud piirangutest sõltumatult. Nii näiteks võib koolikaaslaste või õpilase-õpetaja vaheline küberkiusamine väljuda koolikeskkonnast ning jõuda ohvrini ootamatult igal ajal ning kohas, muu hulgas kodus (Vaillancourt et al., 2017, lk 369).

Küberkiusamise liike on autorid välja toonud hulganisti. Näiteks Willard (2007, lk 1-2) eristab kaheksat üldist küberkiusamise liiki:

1) Sõimamine (flaming) - vihase, ebaviisaka ja vulgaarse sisuga sõnumite saatmine inimese kohta keskkondadesse või isikule endale e-kirja või muude tekstisõnumite kaudu;

2) Ahistamine (harassment) - korduvalt õelate, solvavate ning ebameeldiva sisuga sõnumite saatmine;

3) Mustamine (denigration) - kuulujuttude või laimu levitamine veebikeskkonnas või selle edastamine isikule eesmärgiga kahjustada inimese mainet või sõprussuhteid;

4) Enda esitlemine kellegi teisena (impersonation) - materjali postitamine ja jagamine kellegi teise nime alt, eesmärgiga põhjustada inimesele pahandusi, seada ohtu või kahjustada ohvri mainet või sõprussuhteid;

5) Reetmine (outing) - kellegi saladuste või piinliku informatsiooni ja materjali (pildid, videod) levitamine;

6) Petmine/ülekavaldamine (trickery) - mõjutades inimest rääkima saladusi või avaldama piinlikku teavet ning seejärel selle teabe jagamine veebi;

7) Väljajätmine (exclusion) - tahtlikult ja julmalt inimese ignoreerimine ja veebigruppidest ja kooslustest väljajätmine;

8) Küberjälitamine (cyberstalking) - korduv, intensiivne ahistamine ja mahategemine, mis sisaldab ähvardusi ja tekitab inimeses hirmu.

Lähtume siinses artiklis just Willardi (2007) liigitusest, kuna seda on peetud üheks tuntumaks küberkiusamise liikide jaotuseks (Naruskov \& Luik, 2015, lk 189); lisaks on Kopecký ja Szotkowski (2017b, lk 507) just sellest liigitusest inspireeritult rakendanud seitset konkreetselt õpetajate küberkiusamise liiki: 
1) Küberpeibutamine (Cyberbaiting) - õpetaja provotseerimine ja provokatsioonile järgneva reaktsiooni salvestamine. Peamine salvestamisvahend on telefon, mille abil jagatakse materjali edasi.

2) Õpetajat alandavalt kujutava materjali jagamine - koolis või väljaspool kooli tehtud fotode või videote jagamine ja nende materjalide kommenteerimine.

3) Võltsitud kodulehe loomine õpetaja alandamiseks.

4) Õpetajat alandava võltskonto või profiili loomine (nt suhtlusportaalides).

5) Õpetaja ähvardamine ja hirmutamine.

6) Õpetajalt väljapressimine.

7) Õpetaja kontole sisse häkkimine ja sellele järgnev identiteedivargus.

Alljärgnevalt anname ülevaate õpetajate küberkiusamise kogemusi puudutanud empiiriliste uuringute tulemustest.

\section{Õpetajate küberkiusamine: empiirilised uuringud}

Esimesed viited sellest, et õpetajate-õpilaste suhtlus internetis võib endaga kaasa tuua õpetajate vastu suunatud küberkiusamist, on aastast 2007, mil Kanadas Ontario õpetajate kolledži korraldatud uuringust selgus, et koguni $84 \%$ uuringus osalenud õpetajatest $(\mathrm{N}=1000)$ on isiklikult õpilasepoolset küberkiusamist kogenud ja 41\% uuringus osalejatest olid teadlikud kolleegi küberkiusamise juhtumist (Ontario College of Teachers, 2007). Ka Suurbritannias tehtud uuringus $(\mathrm{N}=377)$ vastas ligi $36 \%$ küsitletud koolipere liikmetest (õpetajad, juhtkond, tugipersonal), et nad on kas ise küberkiusamist kogenud või teadlikud mõne kolleegi juhtumist, seejuures olid $72 \%$ juhtudest uuringus osalejate hinnangul peamisteks küberkiusajateks õpilased; $26 \%$ juhtudel lapsevanemad, 12\% juhtudel töökaaslased (Phippen, 2011, lk 9).

Empiirilistest uuringutest (vt Davenport, 2014; Kopecký \& Szotkowski, 2017b; NASUWT, 2013; Phippen, 2011) nähtub, et õpetajatel on kogemusi mitme küberkiusamise liigiga. Näiteks Suurbritannia õpetajate küberkiusamiskogemusi kaardistanud uuringu $(\mathrm{N}=1522)$ tulemuste kohaselt oli $61,2 \%$ uuringus osalenutest saanud viimase kahe aasta jooksul solvavaid kommentaare (nt Facebooki gruppides ja vestlustes); 38,1\% oli kogenud õpetaja kompetentsi ja käitumist puudutavaid märkusi ning 9,1\% süüdistatud õpilastega kohatus käitumises (NASUWT, 2013). Tšehhi õpetajate uuringust (Kopecký \& Szotkowski, 2017a) ilmnes, et laialt levinud on alandused, laim ja naeruvääristamised, kuid ka libakontode ja vihagruppide loomine, ähvardused ning alandavate piltide levitamine.

Küberkiusamise tagajärjed võivad olla laiahaardelised ning mõjutada nii ohvriks langenud õpetaja eraelu kui ka tööd. Mõned autorid on leidnud, et 
esmalt kannatab küberkiusamise tagajärjel õpetaja pedagoogiline töö, sealhulgas väheneb motivatsioon, tulemuslikkus (Davenport, 2014, lk 118-121), suureneda võib rahulolematus töökohaga ning kaasenda võib soov töölt lahkuda (Ontario College of Teachers, 2007, lk 20-21). Pikema aja vältel küberkiusamise all kannatanud õpetajatel ilmneb rohkem konflikte nii kolleegide ja juhtkonna kui ka õpilastega (Kopecký \& Szotkowski, 2017b, lk 515).

Küberkiusamisega võib kaasneda negatiivne mõju ka õpetaja eraelule ja tervisele. Küberkiusatud pedagoogidel on rohkem konflikte pereliikmetega (Kopecký \& Szotkowski, 2017b, lk 515), nad kogevad stressi, ärevust, nende enesekindlus kahaneb (Davenport, 2014, lk 120-121) ja nad hakkavad ennast süüdistama (Kopecký \& Szotkowski, 2017b, lk 511-512). Vaimsete ja sotsiaalsete raskuste kõrval võib küberkiusamine mõjutada negatiivselt ka õpetaja füüsilist tervist. Näiteks võivad küberkiusamise ohvriks langenud pedagoogid kogeda unehäireid, pea- ja kõhuvalusid, neil võib nõrgeneda immuunsüsteem ja tekkida raskusi ka keskendumisvõimega (ibid.).

\section{Õpetajate küberkiusamise ennetus- ja lahendusmeetmed}

Kahtlemata saavad õpetajad ise panustada sellesse, et vähendada küberkiusamise ohvriks langemise tõenäosust. Näiteks on oluline, et õpetajad leiaksid sotsiaalmeediat kasutades tasakaalu oma professionaalse ja eraelulise identiteedi vahel (Atay, 2009), sealhulgas hoiduksid liigsest eraelulise tekstilise ja visuaalse info jagamisest ja muudaksid võimalike ebameeldivuste vältimiseks oma sotsiaalmeediakontode privaatsussätteid. Tihtipeale ei pruugi aga õpetajate (peamiselt eakamate pedagoogide) digitaalne kirjaoskus olla piisavalt hea (nt ei osata negatiivset sisu blokeerida, veebikeskkondade administraatoritega kontakteeruda), mistõttu võib ka internetis tekkinud probleemidele reageerimine olla takistatud (Kopecký \& Szotkowski, 2017b, lk 515). Küberkiusamise temaatikat uurinud autorid (nt NASUWT, 2013, lk 11) näevadki seetõttu vajadust tõsta töötajate teadlikkust sotsiaalmeediaga kaasnevatest ohtudest. Selleks, et õpetajad saaksid iseennast küberkiusamisega kokku puutudes aidata, tuleks Kopecký ja Szotkowski (2017b, lk 515) sõnul arendada õpetajate teadmisi nii psühholoogiast kui ka seadustikust, et küberkiusamise ohvriks sattudes osataks juhtumile teadlikult reageerida ja tuntaks oma õigusi.

Kopecký ja Szotkowski (2017b, lk 515) on veendunud, et õpetaja küberkiusamise ohvriks langemise korral on igakülgne koolipoolne toetus väga vajalik. Esmajärjekorras on tähtis, et küberkiusamist kogenud õpetajad tunnetaksid, et neil on võimalik abi ja toetuse saamiseks pöörduda kooli juhtkonna poole. Näiteks Ühendkuningriigis tehtud uuringu (NASUWT, 2013, lk 9-10) kohaselt ei informeerinud koguni 36\% küberkiusatud koolipere liikmetest 
$(\mathrm{N}=1522)$ juhtumist kooli juhtkonda, sest enamik küberkiusatutest $(53,2 \%)$ leidis, et probleemi lahendamiseks ei saa midagi teha. Märkimisväärne osa $(29,1 \%)$ koolipere liikmetest ei uskunud ka, et nende juhtumit piisavalt tõsiselt võetaks, või nad hoidusid kooli juhtkonda informeerimast kogemusega kaasneva häbitunde tõttu (17\%) (ibid.). On märkimisväärne, et juhtkonda teavitama jätnute seas oli ka neid (6,4\%), kes olid varem sarnase küberkiusamise juhtumi korral kooli juhtkonda teavitanud, kuid ei saanud enda hinnangul piisavalt toetust (ibid.).

Empiiriliste uuringute (Kopecky \& Sztkowski, 2017b; NASUWT, 2013) tulemused annavad märku sellestki, et paljudes koolides puuduvad reeglid või protseduurid, mida küberkiusamise korral kohaldada. Näiteks Ühendkuningriigis tehtud küberkiusamise uuringus kinnitas $43,7 \%$ osalenud õpetajatest, et nende koolis pole kehtestatud protseduure, mida kohaldataks õpetaja küberkiusamise ohvriks langemise korral (NASUWT, 2013, lk 10). Isegi kui koolides on asjakohased dokumendid olemas, ei pruugi koolid neid järgida, ei käitu protseduuride kohaselt või teevad lahenduste rakendamisel vigu (Kopecký \& Szotkowski, 2017b, lk 515).

Tagamaks õpetajale kaitset küberkiusamise eest, soovitavad Kyriacou ja Zuin (2016, lk 270) käsitleda küberkiusamist näiteks riiklikes õppekavades. Ka teised uurijad (Kopecký \& Szotkowski, 2017b, lk 515) on seda meelt, et kool võiks välja töötada kiusamist ennetavaid programme ja nn kriisikava (nt lahendusprotseduuride kirjeldused), mis võimaldaks probleemse teemaga aktiivselt tegeleda. Enamgi veel, Kopecký ja Szotkowski (2017b, lk 515) leiavad, et selleks, et koolis ei esineks ega tolereeritaks küberkiusamist, peaks koolil olema küberkiusamise suhtes nulltolerants ning määratud üleastujatele asjakohased karistused. Mõned teised autorid (nt Kyriacou \& Zuin, 2016, lk 270) rõhutavad seevastu karistuste määramise asemel koolipoolse sobiliku reageeringuna pigem vajadust kuulata ära küberkiusamisega seotud osalised (sh kaasaminejad) ning soodustada küberkiusaja ja õpetaja leppimist.

Õpetajatele, kellel on olnud kogemus mingisuguse negatiivse juhtumiga, oleks vaja tagada võimalus saada psühholoogilist nõustamist ja tuge (Daniels, Bradley, \& Hays, 2007, lk 654). Kauppi ja Pörhola sõnul (2012, lk 1062) võivad õpetajad vajada kahte sorti abi: 1) emotsionaalset tuge, mis aitaks õpetajal ennast ohvrina aktsepteerida; 2) otsest sekkumist, mis aitaks kiusamist lõpetada, tõkestada ning seeläbi vähendada kiusamisest tulenevat õpetaja ebakindlust ja stressi. Kolleegidevahelisest suhtlusest võib samuti olla abi tekkinud probleemide lahendamiseks (Kyriacou, 2001, lk 31). Seega nagu tavakiusamise juhtumite puhul (Özkilic \& Kartal, 2012, lk 3439), tuleks ka efektiivse küberkiusamise juhtumite lahendamise ning kvaliteetse õpetajate nõustamise tagamiseks koolitada kooli töötajaid. 


\section{Metoodika}

\section{Valim}

Valimi moodustamisel lähtuti kriteeriumidest, mis võimaldaksid saada võimalikult süvitsiminevat andmestikku õpetajate personaalsest kogemusest. Kriteeriumid olid järgmised:

1) õpetajal on isiklik kogemus õpilasepoolse küberkiusamisega;

2) õpetaja on praegune või endine üldhariduskooli pedagoog;

3) küberkiusamise kogemuse juures ei oma tähtsust selle korduvus, tegemist võib olla ka üksikjuhtumiga.

Intervjueeritavate leidmisel kasutati lumepallimeetodit, mille puhul aitavad valitud informandid kaasata teisi inimesi, kes sobivad uuringu valimi tunnustega. Seda meetodit kasutatakse siis, kui tegemist on raskesti kättesaadava sihtrühmaga või inimestega, kes ei soovi nähtusega seotust avalikustada (Salmons, 2010). Lumepallimeetodit kasutades kontakteeruti esmalt inimestega enda tutvusringkonnast palvega jagada koolisüsteemiga seotud inimeste kontaktandmeid, kelle kaudu oleks võimalik saada teavet õpetajate ning nende küberkiusamise kogemuste kohta. Saadud kontaktide hulka kuulusid koolijuhid, õpetajad, kooli tugistruktuuri töötajad ning õpetajatega seotud organisatsioonid ja nende liikmed. Informantide leidmisel tehti aktiivset koostööd Eesti Õpetajate Liidu ja SA-ga Kiusamisvaba Kool.

Suurema hulga inimesteni jõudmiseks avaldas artikli esimene autor 3. jaanuaril 2019 Facebookis õpetajatele suunatud videoüleskutse uuringus osalemiseks. Videot jagati 267 korda ning vaadati 31000 korda (Jürisaar, 2019). Koostöös SA-ga Kiusamisvaba Kool näidati videoüleskutset ka KiVA koolide talvekoolis 3. jaanuaril 2019. Tänu video vaatamisele jõudis uuringusse mitu õpilasepoolse küberkiusamise kogemusega õpetajat.

Uurimuse lõplikku valimisse kuulus 14 praegust või endist üldhariduskooli õpetajat (12 naist, 2 meest) (vt tabel 1). Valimisse kuulusid õpetajad, kelle töökarjääri pikkus on olnud kuni viis aastat või pikem kui neliteist aastat. Õpetajaid, kes on pigem lühema tööstaažiga (kuni viis aastat), oli kokku kuus $(\mathrm{N}=6)$. Pigem pika tööstaažiga (üle 14 aasta) õpetajaid oli valimis kokku kaheksa $(\mathrm{N}=8)$.

Tabel 1. Intervjueeritud õpetajate tööstaaž

\begin{tabular}{|lccccccc|}
\hline \multicolumn{2}{l}{ Tööstaaž aastates } & & & & & Kokku \\
\hline kuni 5 & 3 & 3 & 3,5 & 0,5 & 4 & 5 & 6 \\
\hline $10-20$ & 14 & 18 & 19 & 20 & & 4 \\
\hline üle 20 & 32 & 30 & 21 & 23 & & 4 \\
\hline
\end{tabular}


Intervjuude kestus varieerus ning sõltus suuresti õpetajate isiksusest ja kogetud küberkiusamise juhtumi olemusest. Intervjuude salvestusi kogunes kokku 26 tundi ja 13 minutit, keskmine intervjuude kestus oli 1 tund ja 52 minutit. Transkribeeritud ja analüüsitava materjali maht oli 419 lehekülge. Uurimuse intervjuud tegi artikli esimene autor.

\section{Andmekogumismeetod}

Kuna uurimus käsitleb väga tundlikku teemat ja keskendub uuritavate arusaamade ja kogemuse lahtimõtestamisele lähtuvalt iga indiviidi tõlgendustest, on uuringuks valitud kvalitatiivne uurimisviis, mis toetab uurimise eesmärki ja olemust (Laherand, 2008, lk 15). Uuringu empiirilised andmed on kogutud poolstruktureeritud individuaalintervjuu meetodit kasutades, kuna meetod aitab paremini mõista uuritavat nähtust, pakkudes intervjueeritavale võimalust end vabalt väljendada ning vahendada oma tundeid, hoiakuid, seisukohti ja teadmisi (Salmons, 2010).

Kuivõrd küberkiusamise kogemused on valus teema, pakuti intervjueeritavale võimalust valida, kas intervjuu tehakse silmast silma kohtudes, telefoni teel või interneti vahendusel (heli- või videokõnena Facebookis, Skype’is). Enamik valimisse kuulunud õpetajaid eelistas intervjuude vormina reaalset kohtumist ja isiklikumas vormis vestlemist. Intervjuu vormid jaotusid järgmiselt: kümne õpetajaga toimus silmast silma kohtumine, kahe õpetajaga toimusid intervjuud telefoni teel ning kahe pedagoogiga videokõnena internetis (Skype, Facebook). Silmast silma kohtumised toimusid kuuel korral kohvikus, kolmel korral koolis ja ühel korral õpetaja kodus. Veebi vahendusel tehtud intervjuudel eelistasid õpetajad suhelda video vahendusel, kus uurijal ja õpetajal oli võimalik teineteist näha.

Enne intervjuud selgitati informantidele uuringu olemust ja sellega seonduvat protseduuri. Igale intervjueeritavale edastati e-kirja teel nõusoleku vorm, mis tuli enne intervjuud põhjalikult läbi lugeda ning seejärel digiallkirjastada. Soovi korral oli nõusoleku vormiga võimalik tutvuda ning see allkirjastada füüsiliselt paberil enne intervjuud.

Intervjuu kava koosnes neljast küsimusteplokist: 1) sissejuhatavad küsimused õpetaja tööstaaži, õpetatavate vanuseastmete ja õpetajaks olemise kohta; 2) küsimused ópetaja arusaamadest (tava)kiusamisest, kogemustest kiusamisega ja küberkiusamise defineerimisest; 3) õpetaja isiklik õpilasepoolse küberkiusamise kogemus, kaasnenud tagajärjed ja üldised toimetulekumeetmed juhtumi lahendamisel (nt „Teid on palutud osalema sellel intervjuul, sest teil on olnud kokkupuuteid õpilasepoolse küberkiusamisega. Palun kirjeldage enda kogemusi, mis täpsemalt juhtus?“; „Kas ja kelle poole te sel hetkel 
toetuse ja abi saamiseks pöördusite?"); 4) küsimused võimalikest meetmetest õpetaja küberkiusamisega toimetulekuks (nt „Millised on teie arvates võimalikud meetmed õpetajate küberkiusamisega tegelemiseks?"; „Mida saaks kool teha selleks, et taolisi olukordi vältida / küberkiusamise juhtumeid ära hoida?").

Kõigepealt tehti prooviintervjuu, mille järel kohandati intervjuukava ning muudeti osade intervjuuküsimuste sõnastust täpsemaks ja arusaadavamaks. Siinse artikli fookuses on kolmanda ja neljanda küsimusteploki tulemused.

\section{Andmeanalüüsi meetod}

Intervjuude analüüsimiseks kasutati kvalitatiivse sisuanalüüsi meetodit, kuna selle kaudu on võimalik saada ülevaade uuritavast tekstist kui tervikust ja see võimaldab keskenduda teksti peamistele ja olulistele tähendustele, toetades ka ridade vahele peidetu analüüsimist (Kalmus, Masso, \& Linno, 2015). Valitud meetod on eriti õigustatud mõne vähem uuritud teema käsitlemisel (Laherand, 2008).

Intervjuude transkriptsioonide analüüsiprotsessis kasutati tarkvara MAXQDA. Kodeerimisel kasutati sisuanalüüsis induktiivset lähenemist, mis aitab paremini mõista ja uurida intervjueeritute tõlgendusi ja tähendussüsteeme (Kalmus, Masso, \& Linno, 2015). Analüüsiprotsessiga alustades loeti esmalt intervjuude transkriptsioonid põhjalikult läbi. Induktiivsel ehk avatud kodeerimisel tuletatati koodid tekstist ning anti tekstilõikudele, lausetele või sõnadele üksikasjalikud tähendused (ibid.). Kombineerides rida-realt analüüsi, mille käigus anti igale lausele ja lause osadele (sõnad, väljendid) teksti sisu kirjeldavad koodid, ning lause ja paragrahvi analüüsi; tekkisid esialgsed koodid, mis hakkasid intervjuust intervjuusse korduma: näiteks õpetajate küberkiusamise kogemused; küberkiusamise tagajärjed õpetaja tööelule, igapäevaelule ja sotsiaalmeedia kasutamisele; õpetajate küberkiusamise toimetulekumeetodid; õpetajate arvamuste põhjal välja tulnud soovitused õpetajate küberkiusamisega tegelemiseks.

Teises analüüsietapis koondati sarnased koodid lähtuvalt uuringu eesmärkidest ja uurimisküsimustest kolme peateema (õpetajate küberkiusamise liigid, küberkiusamise tagajärjed ja võimalikud lahendused) ning kaasnevate alateemade alla. Näiteks õpetajate küberkiusamise liikide kategoriseerimisel toetuti Willardi (2007) ning Kopecký ja Szotkowski (2017b) välja toodud küberkiusamise liigitustele, liites esialgsed koodid tähendusliku kokkulangevuse või läheduse alusel. Näiteks paigutati analüüsi käigus õpetajate küberkiusamise kogemusi iseloomustav kood „laim ja valeinfo jagamine“ lähtuvalt Willardi (2007) küberkiusamise liikide jaotusest alaliigi „mustamine veebis“ alla; ja „identiteedivarguse“ kood Willardist (2007) lähtuvalt alaliigi „enda esitlemine kellegi teisena" alla. Kodeeris artikli esimene autor üksinda. 


\section{Tulemused}

\section{Õpetajate kogemused õpilasepoolse küberkiusamisega}

Toetudes Willardi (2007) ning Kopecký ja Szotkowski (2017b) küberkiusamise liigitustele, nähtus meie intervjuudest, et valimisse kuulunud õpetajad olid kogenud kuut liiki õpilasepoolset küberkiusamist: 1) õpetajat alandavalt kujutava visuaalse materjali (eelkõige töödeldud fotode) jagamist; 2) vihase, ebaviisaka ja vulgaarse sisuga e-kirjade ja kiirsuhtlusprogrammi sõnumite saamist; 3) mustamist veebikeskkonnas; 4) ahistamist veebikeskkonnas; 5) küberjälitamist; ja 6) kellegi teisena esinemist (nt identiteedivargus). Lisaks enda vahetu kogemuse jagamisele oskasid pea kõik uuringus osalenud õpetajad rääkida ka mõne enda kolleegi või muu kooli õpetaja küberkiusamise juhtumist.

Mitme intervjueeritava küberkiusamiskogemus oli seotud õpetajat alandavalt kujutava visuaalse materjali (eelkõige töödeldud fotode) levitamisega. Nende küberkiusamise juhtumite puhul oli õpilane võtnud õpetajast kas internetist avalikult üleval oleva foto (nt õpetaja Facebooki või Instagrami kontolt, ühisest Facebooki vestlusest õpilastega, kooli sotsiaalmeediakanalilt või koduleheküljelt) või teinud õpetajast pilti klassiruumis või mõnes avalikus kohas, lisanud fotole vulgaarseid täiendusi ja levitanud seejärel avalikult kas õpilase sotsiaalmeediakontol, kooli meemide Instagrami kontol või sotsiaalmeediakanalite sisegruppides (nt Facebooki Messenger, Facebooki grupid, Snapchat). See küberkiusamise liik oli intervjueeritavate kogemustest kõige sagedamini seotud meemidega. Näiteks ühel juhul võtsid õpilased koolisündmuse pildigaleriist õpetajast fotod ning postitasid õpetaja sõnul nõmeda pealkirjaga õpilaste poolt loodud kooli meemide lehele.

Kogemused opetajat alandavalt kujutava visuaalse materjali, sealhulgas töödeldud fotode jagamisega olid üldiselt ühekordsed küberkiusamisjuhtumid. Samas ilmnes ühe intervjueeritava kogemusest, et õpetajat võib ka pikaajaliselt ja korduvalt alandava visuaalse materjali jagamise teel küberkiusata. Näiteks ühel juhul pildistasid õpilased õpetajat tunnis, töötlesid tehtud fotosid ja levitasid kaasõpilaste seas, lisades muu hulgas õpetajat enesetapule õhutavaid sõnumeid.

Selle óppimise ajal siis oligi, võeti siis vaikselt kotist raamat. Raamatuga koos ilmus muidugi ka telefon, millega tehti pilti. /.../ Siis tehti ka minust ja seda pilti moonutati ja pandi ühe looma selga ja siis ... noh ... ja siis sinna juurde oli ka siis selgitavad tekstid kuni sinnamaani, et ka nooltega, mida ühelt poolt ja teiselt poolt nagu teha võib ... selline hästi labane. Ja muidugi välja toodud, et „see vana v..., mis mõttes, * (protest ópetaja tegevuste vastu).“ Selline nagu ... tekstidega pilt. Ja see läks siis ringlema. (Õ3) 
Intervjueeritute kogemusele toetudes võib väita, et õpilased levitasid õpetaja kohta käivat materjali enamjaolt privaatsetes veebigruppides ja -vestlustes. Küberkiusamise ohvrid said sellistest juhtumitest teada kolleegi või mõne kaasópilase kaudu.

Mitmele uuringus osalenud õpetajale olid õpilased saatnud ka vihaseid, ebaviisakaid ja vulgaarse sisuga e-kirju ning kiirsuhtlusprogrammi sõnumeid (nt Facebook Messengeris). Enamikul puhkudel oli tegemist üksikjuhtumitega, kuigi ühel valimisse kuulunud õpetajal oli ka kogemus, mille puhul õpilane edastas talle ebaviisakaid ja vulgaarseid sõnumeid Facebooki pikema aja jooksul.

Intervjuudest ilmnes, et õpetaja võib küberkiusamise ohvriks langeda ka kellelegi teisele appi minnes. Nimelt hakkasid õpilased ühte valimisse kuulunud õpetajat veebis ahistama pärast seda, kui ta otsustas sekkuda kolleegi küberkiusamisse. Konkreetse juhtumi puhul oli anonüümseid küberkiusajaid mitu ning õpetajat lisati pikema aja jooksul korduvalt kiirsõnumite vahetamise platvormi vestlustesse, kus teda ähvardati ja solvati.

Hoolimata sellest, et ma ütlesin, et see on illegaalne tegevus, mind ei võetud kuulda. Kedagi ei huvitanud, et ma soovisin seda situatsiooni lópetada, mille nad olid loonud sinna Facebooki Messengeri suhtlusvõrku. Ma sain igasuguse vulgaarse sisuga sõnumeid aja vältel, kevad 2018 kuni jaanuar 2019. See järjepidev info või osalemine nendes roppudes vestlustes ja minu kaasamine sinna ja minu suunal roppuste välja ütlemine. Ja ähvardamine ka. /.../ Enamustes on siin ikkagi selline kutse, umbes et "Jou, ${ }^{*}(\tilde{o}$ petaja nimi), vana v..., kus Sa oled?" , „T..., kuuled vä?“. (Õ11)

Küberkiusaja anonüümseks jäämise korral on õpetajal end veelgi keerulisem kaitsta. Seda illustreerib ühe intervjueeritava kogemus, kus õpilane saatis talle anonüümse e-kirja, mida õpetaja tajus ähvardusena, nii et õpetajat valdas pikka aega kartus selle pärast, mida õpilane võib korda saata.

Uuringus osalenud õpetajatel oli kogemusi ka mustamisega veebikeskkonnas ehk olukordadega, kus õpetaja kohta jagati internetis ebakorrektset ja õela sisuga infot. Näiteks ühe intervjueeritava puhul tegid õpilased õpetajaga seotud veebiartikli kommentaariumis õpetaja kohta negatiivse sisuga anonüümseid postitusi ning avalikustasid isiklikku infot. Teisel intervjueeritaval oli kogemus olukorraga, kus õpilane lisas kooli Facebooki avalikule lehele õpetaja kohta negatiivse sisuga postituse. Samal ópetajal oli ka mustamiskogemus, kus õpilane lisas enda isikliku Facebooki profiilile postituse, milles kritiseeris ópetaja õpetamismeetodeid ja eraelulisi nüansse. 
See Facebooki postitus tookord, /.../ mis ópilane oli pannud oma lehele. See ei meeldinud ka absoluutselt sellepärast, sest see oli täiesti ebaõiglane. Ta oli nagu vale. Sest ei ole nii. /.../ Mmm ... (mõtleb) ma olin ikka häiritud. Vastik oli. No ei ole hea lugeda mingi suvalise inimese kuskilt postitusest ikkagi enda täisnime onju ja enda noh ... väga ebamugav oli. Väga halb oli. (Õ5)

Intervjueeritute seas oli ka õpetaja, kes oli sattunud järjepideva küberjälitamise ohvriks. Konkreetse juhtumi puhul hakkas õpilane sotsiaalmeedias õpetajat aktiivselt jälgima ja andis klassiruumis kõigile teada, et on õpetaja sotsiaalmeedias toimuvaga kursis. Õpilane tegi mitukümmend libakontot ja proovis õpetajale sõbrataotluste saatmisega pääseda ligi rohkemale informatsioonile.

Ja siis mingi hetk avastas, et mul on Instagram. Mul on kinnine konto, et seda näevad siis inimesed, keda ma tahan, et seda näevad ja siis tuli ka, et „õpetaja, ma tean, et sul on Instagram“. Ja järjest see jätkus ja jätkus ... /.../ Ja noo, ta käis klassis ringi ja näitas, et ópetajal on selline pilt jaa ... no kõik sellised asjad. Õnneks mul ei olnud seal mitte midagi hullu, täiesti tavalised pildid, aga ikka mind see häiris, et niimoodi käib ... /.../ Ja mingi hetk nägin, et ta saatis Instagramis mulle selle jälgimistaotluse. Panin, et ma ei nõustu sellega ja siis hakkas järjest tulema ja tulema ja lõpuks panin ta kontole blokeeringu peale, et rohkem ei näeks. Ja siis tuli järgmine konto. Kordus täpselt sama asi ... ja järgmine ja... (Õ 2 )

Üks valimisse kuulunud õpetaja oli kogenud ka olukorda, kus tema sotsiaalmeedia kontost tehti dubleering ning hakati justkui tema enda nime alt libakonto kaudu levitama veidra sisuga postitusi, ehk ta oli langenud identiteedivarguse ohvriks. Kuu peale libakonto avastamist ja sulgemist oli konto taas aktiivne ja õpetaja nime alt postituste tegemine jätkus.

\section{Võimalikud koolipoolsed ennetus- ja lahendusmeetmed}

Intervjueeritud õpetajate sõnul on õpetajate küberkiusamine õpilaste poolt varjatud ja tundmatu teema, mida on vaja laiemalt uurida ja mille ennetus- ja lahendusmeetmete otsimisega tuleks tõsisemalt tegeleda. Uuringus osalenud ja õpilasepoolse küberkiusamiskogemusega õpetajad nägid väga olulise instantsina õpetajate küberkiusamisega tegelemisel kooli, kuna leiti, et kooli juhtkonna ning kolleegide toel saaks küberkiusamist tõkestada ja aidata ohvriks langenud õpetajal negatiivse kogemusega hakkama saada.

Õpetajad peavad küberkiusamise tõkestamisel suureks probleemiks asjaolu, et õpilasepoolset küberkiusamist kogenud pedagoogid ei julge oma murest rääkida ja koolilt abi paluda. 
No see tekitas minus jõuetut tunnet, et ma ei ole võimeline midagi tegema, et seda ei oleks olemas. Ükskõik, kes ma olen, mul ei ole võimekust sellele asjale piiri tõmmata. See pole minu teha ja ma ei saa kuskilt abi ka. Mitte kedagi ei huvita. Ma pean ise sellega hakkama saama. Ma saangi, aga ma mõtlen sellele, et võib-olla mõni inimene ei saa ise hakkama. Sellepärast ma tulingi täna siia, et seda ei vaikitaks maha, et sellest oleks mingit kasu. (Õ11)

Vaikimist põhjendasid uuringus osalenud osaliselt häbiga kolleegide ja juhtkonna ees, kardetakse etteheiteid, parastamist ja sedagi, et hakatakse kahtlema nende professionaalsuses ja hakkamasaamises.

\begin{abstract}
/.../ Ma selle esimese emotsiooniga midagi ei teinud ja siis järgmisel päeval uurisin ka õpetaja käest ... mul oli isegi ópetaja ees natuke piinlik. Klassijuhataja ees, kes sellega tegeles. /.../ ... kuidagi oli nagu häbi või piinlik ... et ... et selline asi. Ma tundsin küll häbi ja piinlikkust, kui ma läksin õpetaja juurde küsima, et kuule, et selline asi on, et minu pilt võeti. Et ... siis ma küll tundsin häbi. (Õ6)
\end{abstract}

Ka uuringus osalenute seas oli neid, kes nimetatud hirmude tõttu jätsid juhtunu enda teada ja koolis oma probleemist ei rääkinud. Selleks, et julgustada õpetajaid muredest rääkima, peaks intervjueeritavate sõnul kool tagama õpetajas kindlustunde ja teadmise, et kool on igal juhul tema selja taga.

Võib-olla, kui see kohe märkamine ... et kui õpetaja tuleb mingist murest rääkima, et noh. Ma saan aru, et kõigil on kiire ja kõigil on tegevusi, aga kui õpetaja tuleb mingist murest rääkima, et teda kiusatakse, siis seda tuleks kohe esimesel korral väga tõsiselt võtta ja sellele võimalikult vara piir peale panna, sest tegelikult, kui seda ei tehta, siis see veereb nagu lumepall: läheb aina suuremaks ja suuremaks. (Õ2)

Mitme uuringus osalenu meenutustes oli kooli juhtkond suhtunud tema küberkiusamise juhtumisse passiivselt. Kui aga juhtkond peab õpilast olulisemaks ega võta õpetaja muresid prioriteetsena, on ka õpetajal keeruline ennast kaitsta. Uuringus osalenud õpetajad leidsid üksmeelselt, et koolis peaks valitsema nulltolerants õpetajate küberkiusamise suhtes ning nii teemasse suhtumise kui ka tegudega tuleks anda õpilastele märku, et igasugune negatiivne käitumine õpetaja suhtes on vastuvõetamatu. Leiti, et vaid selline suhtumine ja käitumine võib aidata kujundada kooli üldiseid väärtusi, hoiakuid ning soodustada probleemi varajast märkamist ning aktiivset teavitamist pealtnägijate poolt, soodustades seeläbi võimalike küberkiusamise juhtumite ärahoidmist. Intervjuude analüüsist nähtus, et õpetajad, kes olid kooli juhtkonnalt saanud enda hinnangul piisavalt toetust, olid kooliperes (kolleegid, juhtkond) vähem pettunud ning tundsid end võimalike tulevaste probleemide suhtes enesekindlamalt. 
Õpetajate sõnul on küberkiusamise juhtumite lahendamisel sageli takistuseks koolipere vähene teadlikkus nii konkreetsemalt õpetajate küberkiusamisest kui ka küberkiusamisest laiemalt. Vähest teadlikkust peeti ka üheks põhjuseks, miks koolide juhtkonnad ei oska tekkivaid probleeme tõsiselt võtta ega neid lahendada. Intervjuudest selgus, et ka õpetajad ise ei pruugi alati teada, mida üldse küberkiusamiseks pidada, mis on ohvriks langemisel nende õigused või võimalikud lahendused. Selleks, et tagada õpetajate ja juhtkonna teadmised ning teadlikkus probleemist, tuleks õpetajate sõnul korraldada küberkiusamise teemal õppepäevi, koolitusi. Samuti leiti, et õpetajate küberkiusamisest võiks koostada õppematerjale ja lõimida õpetajate küberkiusamist programmidesse ja tunnitöösse, mis käsitlevad õpilastevahelist kiusamist.

Jaa, toimetulekut näiteks. Mitte ópetada, vaid ... vaid pidada loengut, kuidas sellise olukorraga toime tulla, sest ma ise tunnen, et ma ise ilmselt ka eelmisel aastal pool aastat tegelesin olemasoleva jalgratta leiutamisega. Mis ma nü̈̈ peaks tegema? Kuidas käituda? Kuidas jääda iseendaks selles olukorras? Seda infot oleks tahtnud küll, et kuidas teised teinud on või ... et ma ei tunneks väga ennast üksi jäetuna selles olukorras. Kindlasti ópetajatele kuluks sihukesed ... ma ei ütles, et see oleks koolitus, vaid sihukene öppepäev, sest iga õpetaja on tegelikult selles olukorras ohuallikas. Iga õpetaja võib sattuda sellesse olukorda. (Õ3)

Kuigi paljudes koolides käsitletakse küberkiusamist õpilaste omavahelise kiusamise fookuses, oleks õpetajate sõnul vajalik tõsta õpilaste teadmisi ka õpetajate küberkiusamisest, andes signaali, et õpetajate nii nagu kõigi teistegi kiusamine on väär.

Teinekord peakski kontrollima, et kas laps teab, mis sobib ja mis selle tagajärg on. Öeldakse, et nii ei tohi, aga unustatakse öelda, et miks nii ei tohi. See on veel olulisem. /.../ Miks ei tohiks, mis selle tagajärg on? See selgitustöö jääb ka paljuski koolidel tegemata. Me käsime, keelame, aga me ei ütle, miks nii tuleb teha. (Õ7)

Õpetaja küberkiusamise intsidendi lahendamisel peavad õpetajad oluliseks kiusajaga otse suhtlemist ja tema ärakuulamist. Tuleb aru saada, mis oli õpilase käitumise eesmärgid, tagamaa ja kas tegemist oli üldse pahatahtliku kiusuga. Näiteks arvati, et küberkiusamist kogenud õpetajal tuleks õpilasele teada anda, mida tema käitumine õpetajale kaasa tõi ning millised võivad olla teoga kaasnevad tagajärjed. Mõned õpetajad leidsid, et küberkiusamise juhtumite lahendamisel on vajalik protsessi kaasata ka kolmandaid erapooletuid osalisi (nt sotsiaalpedagoog, lastekaitsespetsialist), kes suudaksid seotud osalistesse neutraalselt suhtuda. Intervjueeritud leidsid, et on vaja tagada keskkond, kus 
õpilane oleks koostööle avatud ega tunneks ennast rünnatuna, kuna sellega võivat kaasneda probleemi eskaleerumine. Samas leidsid mõned intervjueeritud, et kiusajad võivad probleemi tõsisemalt võtta (nt õpilane muudab oma käitumist, kiusamine lõpeb), kui nendega vestleb nende jaoks autoriteetsem inimene (nt direktor). Küll aga oleneb palju kiusaja üldisest suhtumisest koolitöötajatesse, sest teatud puhkudel ei pruugi isegi vestlus direktoriga õpilase käitumises positiivset muutust tuua. Näiteks ühe õpetaja kogemuses ei toonud õpilase vestlus direktoriga kaasa küberkiusamise lõpetamist, kuna õpetaja hinnangul oli käitumisraskustega õpilase jaoks muutunud direktsiooni noomitused juba liiga igapäevaseks.

Intervjueeritud õpetajad leidsid, et on oluline lisada õpetajate vastu suunatud negatiivse käitumise teema tervikuna, sealhulgas õpetajate küberkiusamine, kooli regulatsioonidesse, sest see aitaks tagada õpetaja suurema kaitse küberkiusamise ohvriks langemisel. Leiti, et selleks, et õpetaja oleks probleemi lahendama asudes enesekindlam, tuleks kooli kodukorras sätestada, milline käitumine õpetaja suhtes on aktsepteeritav ning millised tagajärjed võivad õpetaja vastu toime pandud negatiivse teoga õpilasele kaasneda. Lahendusmeetmetena pakkusid õpilasepoolse küberkiusamiskogemusega õpetajad välja näiteks õpilasele märkuse kirjutamist, vestlust direktsiooniga, käitumishinde alandamist ja lisatöö määramist. Karmimate meetmetena tõid õpetajad välja käskkirja andmist ja kooli nimekirjast välja arvamist. Intervjueeritud leidsid, et kooli regulatsioonides võiksid olla kajastatud ka täpsed protseduurilised toimingud, mis suunaksid õpetajat operatiivselt probleemile lahendust leidma.

Rangus on selle poole pealt hästi oluline, et muidu väga sotsiaalne vahva keskkond, aga selliste asjade puhul nalja ei oleks. See peab olema reguleeritud nii, et oleks kindel reeglistik selles koolis, mis tekitab selle teadmise, et teatud asjad on taunitavad siin koolis. Mitte niisama, et ma võin teha ja minuga ei juhtu mitte midagi. Et karistamatuse tunnet ei oleks. (Õ14)

Lisaks tegid uuringus osalenud õpetajad ettepaneku, et koolis võiksid olla juhised, mis aitaksid õpetajal paremini lahendada õpetaja professiooniga seotud sotsiaalmeedia kasutamise dilemmasid. Probleemi lahendamisel oleks uuringus osalenud pedagoogide arvates vaja küberkiusatud õpetajale tagada tugistruktuuride, näiteks koolipsühholoogi, haridustehnoloogi või sotsiaalpedagoogi toetus, kes oskab õpetajat nõustada nii tehnilistes küsimustes kui toetada ka psühholoogiliselt.

Õpetajate küberkiusamise tõkestamisel nähti lahendusena ka piirangute seadmist õpilaste nutitelefonide ja tehnika kasutamisele koolis (nt piirangud avalikele wifi-ühendustele, telefonide kasutamisõigusele, kooli tehnikaseadmetes teatud veebikeskkondade kasutamisele). 
Ma usun, et analoogse süsteemi alla annaks panna ka kõik tahvelarvutid tunnis. Ma jagan tahvelarvutid välja, et ka seal on ta juba häälestatud nii, et ta ei teeks pilte, ei filmiks, ei võtaks ühendust sotsiaalvõrgustikega, vaid seal on tõesti konkreetsed ligipääsud konkreetsetele asjadele. (Õ3)

Lisaks toetas üks intervjueeritav näiteks ka klassiruumidesse kaamerate paigaldamise ideed. Samas tuleb igasuguste piirangute seadmisel arvestada, et isegi piirangute seadmine ei pruugi soovitud tulemusi anda. Seda illustreerib ühe uuringus osalenud õpetaja kogemus, kus õpilasepoolne küberkiusamine toimus ametlikult nutivabaks kuulutatud koolis.

\section{Arutelu}

Intervjuudest nähtus, et Eesti üldhariduskoolide õpetajad on kogenud õpilaste poolt kuut liiki küberkiusamist. Sarnaselt varem tehtud uuringutega (vt Kopecký \& Szotkowski, 2017b; NASUWT, 2013; Phippen, 2011) olid ka siinses uuringus osalenud õpetajad kõige sagedamini kokku puutunud õpetajat alandavalt kujutava visuaalse materjali (eelkõige töödeldud fotode) jagamisega ning saanud õpilastelt vihaseid, ebaviisakaid ja vulgaarse sisuga e-kirju ning kiirsuhtlusprogrammi sõnumeid. Samuti oli neid nii avalikes kui ka privaatsetes veebikeskkondades mustatud. Sellist liiki küberkiusamise esinemist õpetajate seas on täheldanud teisedki uurijad (vt Kopecký \& Szotkowski, 2017b; NASUWT, 2013; Phippen, 2011). Ühel õpetajal oli kogemus ka õpilasepoolse küberjälitamisega, samal ajal kui teist valimisse kuulunud ópetajat ahistati veebis pikema aja vältel. Ühele uuringus osalenud õpetajale oli tehtud ka Facebooki libakonto, mille vahendusel õpetaja nime alt probleemseid postitusi tehti, ehk küberkiusajad esinesid õpetajana. Kuna uuringuid, mille fookusesse on võetud õpetajate küberkiusamine õpilaste poolt, on endiselt napilt, ei saa välistada võimalust, et ka õpetajate kogemused õpilastepoolse küberkiusamisega on märkimisväärselt eripalgelisemad, kui siinsest analüüsist nähtub. Seetõttu on lisauuringute tegemine sel teemal väga oodatud.

Intervjuudest nähtus, et õpetajad näevad kooli olulise osalisena õpilastepoolse küberkiusamise juhtumite lahendamisel. Sarnaselt mitmete autorite arvamusega (vt Kopecký \& Szotkowski, 2017b; Kyriacou \& Zuin, 2016; NASUWT, 2013) pidasid ka siinses uuringus osalenud ópetajad oluliseks, et koolides valitseks õpetaja vastu suunatud negatiivse käitumise suhtes nulltolerants ja (küber)kiusamisohvritele võimaldataks vajaminevat tuge. On märkimisväärne, et need uuringus osalenud õpetajad, kes hindasid enda koostööd kooliga juhtumi lahendamisel positiivselt ning tundsid, et olid saanud koolilt vajalikku tuge, olid ka oma kiusamisjuhtumijärgses suhtumises 
kooliperre positiivsemad. Enamgi veel - kooli toetust tunnetanud intervjueeritavad leidsid üldiselt, et saavad ka tulevaste probleemide korral kooli abile loota.

Sarnaselt Kopecký \& Szotkowski (2017b) soovitustega ilmnes ka meie intervjuudest, et aspektid, mida õpilasepoolset küberkiusamist kogenud õpetajad juhtumiga hakkamasaamiseks oluliseks peavad, on üsna sarnased. Inspireeritud Kopecký ja Szotkowski (2017b) mõtetest ning enda empiirilise uuringu tulemustest, toome välja mõned soovitused, millest koolid võiksid õpetajate küberkiusamisjuhtumite lahendamisel edaspidi lähtuda.

\section{1) Õpetaja väärtustamine ja nulltolerants õpetaja (küber)kiusamise suhtes}

Intervjueeritud õpetajad tunnetasid, et kooli juhtkond ei seisa tihtipeale probleemide korral õpetaja selja taga ning koolides pole piisavalt selgelt määratletud, milline õpilastepoolne käitumine ei ole aktsepteeritav. Nii intervjuudest kui ka varasematest uuringutest (vt NASUWT, 2013) ilmneb, et suur osa õpilasepoolse küberkiusamise ohvriks langenud õpetajatest ei informeeri juhtunust kooli juhtkonda, kuna neid valdab juhtunu pärast suur häbitunne ja hirm. Koolipoolse kindla toetuse korral tunneb õpetaja ennast väärtustatuna ning võib probleemide korral julgemalt koolipere poole pöörduda, et ühiselt lahendusi otsima asuda. Uuringus osalenud õpetajate arvates tuleks koolist kujundada keskkond, kus õpilased tajuvad ja näevad, et õpetajat peetakse kooli alustalaks, kes on hinnatud ja hoitud. Sellest intervjueeritavate mõttest ajendatult leiame, et õpetajate vär̈rtustamist tasuks selgemini esile tuua nii kooli üldisi väärtusi sõnastades kui ka ühise kooliperena neid väärtusi rakendades. Näiteks võiksid õpetajad õppeaasta alguses oma tundides õpilastega kooli väärtuste üle arutleda ning luua nende baasil ühised käitumisreeglid. Õpilasi kaasates võivad nad tajuda suuremat vastutust värrtustest lähtumisel, sest neid on kaasatud nende tõekspidamiste mõtestamisse ning reeglid on üheskoos kokku lepitud. Probleemide tekkimisel on õpetajal võimalik kokkulepete juurde naasta ning olukorda nende baasil lahendama hakata.

\section{2) Koolipere teadlikkuse tõstmine õpetajate küberkiusamisest}

Selleks, et saaks üldse alustada küberkiusamise tõkestamisega, on tarvis mõista probleemi olemust. Valimisse kuulunud õpetajate sõnul on tarvis tõsta nii õpetajate, õpilaste kui ka juhtkonna teadmisi õpetajate küberkiusamisest näiteks koolituste, õppematerjalide ja programmide kaudu, et tagada teema tõsiseltvõetavus ja seega luua ka eeldused efektiivseks probleemi märkamiseks, sellega tegelemiseks ja ennetamiseks. Kuna tihtipeale on kiusamisvastaste programmidega liitumiseks vaja leida rahalisi ressursse, mis võib paljude koolide jaoks olla takistav faktor, leiame, et kiusamist ja küberkiusamist tõkestada 
aitavad programmid (nt KiVa) võiksid olla riiklikult finantseeritud, et koolide osalemisvõimalused ei jääks eelarvepiirangute taha.

Teadlikkuse tõstmine kogu koolipere hulgas on oluline kasvõi seetõttu, et noorte ja täiskasvanute tõlgendused küberkiusamise kohta võivad märkimisväärselt erineda (Marwick \& boyd, 2014; Naruskov, 2020). Kuna internetikeskkonnas on teo tahtlikkust kohati väga raske hinnata (Rao et al., 2018; Vaillancourt, Faris, \& Mishna, 2017, lk 369) ja ka kiusaja ise ei pruugi alati enda tegude tõsidust mõista (Menesini \& Nocentini, 2009, lk 230), on eriti tähtis püüelda kõigi jaoks üheselt mõistetava tõlgenduse poole. Probleemi teadvustamisele ja ühise mõistmise saavutamisele võiks meie hinnangul kaasa aidata see, kui küberkiusamist kogenud õpetajad enda kogemust ning sellega kaasnevaid tagajärgi kogemusõppe vormis kolleegide ja õpilastega jagaksid. Õpetaja heaolu ja probleemide lahendamine võiks muu hulgas sobida ka personalikoolituse teemaks. Näiteks võiks sellistel kohtumistel mängida õpetajatega läbi küberkiusamise olukordi ehk rakendada meetodit, mida on nii koolitustel kui ka õpilastele suunatud sotsiaalsete oskuste olümpiaadi käigus rakendanud veebipolitseinikud (Jürisaar, 2019). Õpilasepoolse küberkiusamise kogemusi võiksid õpetajad majaväliseid eksperte kaasates lahendada ning mõtestada ka rühmasupervisioonide käigus. Sellised läbimängimised ning kogemuste jagamised aitaksid ühest küljest arendada omavahelist usaldust ja teineteisemõistmist, teisalt aga õpetaksid koolipere liikmeid küberkiusamisjuhtumeid märkama ning neile teadlikumalt reageerima.

Intervjueeritud õpetajad leidsid, et oluline on koolis luua selline keskkond, mis soodustaks kiusaja mõistmist ning probleemiga avatult tegelemist. Sarnaselt Kyriacou ja Zuiniga (2016) leidsid ka meie uuringus osalenud, et õpetajate küberkiusamise intsidentidega tegelemisel tuleb eelhoiakuteta ära kuulata kõik asjassepuutuvad osalised. Leiti, et vaid avatud suhtluse toel võiksid kõik osalised juhtunust õppida, taastuda kaasnenud raskustest ja suuta koolis optimistlikult edasi tegutseda.

\section{3) Õpetajate küberkiusamise sätestamine kooli regulatsioonides}

Uuringus osalenud õpetajate arvates peaks olema koolide dokumentides selgemalt rõhutatud õpetajate väärtustamine ning sätestatud, et õpetaja vastu suunatud negatiivse käitumise korral tagatakse õpetaja kaitse. Sarnaselt varasemates uuringutes leituga (Kyriacou \& Zuin, 2016) tõdesid ka siinses uuringus osalenud õpetajad, et õpetajate küberkiusamise vastased meetmed võiks olla sätestatud kooli õppekavades ja juhtumite lahendamiseks võiks rakendada küberkiusamise ennetusprogramme ja protseduurireegleid (Kopecký \& Szotkowski, 2017b). Eeltoodust ajendatult leiame, et tasuks põhjalikult kaaluda üleriigilisi suunitlusi, mis nõuaksid kõikidelt koolidelt vajalikke õpetajate 
küberkiusamise ennetusmeetmeid ja sätestatud protseduure juhtumitega tegelemiseks. Konkreetsete lahendusmeetmete ja võimalike kaasnevate tagajärgede sätestamisel oleks sel juhul igale koolile tagatud alus, millele juhtumite lahendamisel tugineda. See annaks ka õpilasepoolse küberkiusamise ohvrile kindluse ja konkreetse plaani, mis aitab intsidendiga kohe tegelema hakata. Loomulikult on seejuures oluline, et koolid ise kehtestatud reeglitest kinni peaksid.

\section{4) Õpetajale tugistruktuuridepoolse toe tagamine}

Varasemad uuringud nii koolivägivalda (Daniels et al., 2007) kui ka kiusamist kogenud õpetajatega (Özkilic \& Kartal, 2012) on näidanud, et psühholoogilise ja tehnilise toe olemasolu on kiusamisjuhtumi lahendamiseks väga oluline. Ka meie informantide kogemustest nähtus, et õpilasepoolset küberkiusamist kogenud õpetajad väärtustaksid sellist abi kõrgelt. Nii võiks tehniliselt õpetajatele suureks toeks olla haridustehnoloog, kes oskab suunata ja vajaduse korral õpetajat veebi riputatud materjalide eemaldamisel abistada. Kuna tänapäeval tuginevad koolid aina enam tehnoloogiale, võiks õpetajaid koolitada internetiturvalisuses ja digitehnoloogia (sh sotsiaalmeedia) kasutamises, et nad oskaksid rakendada peamisi privaatsus- ja turvasätteid, mis võivad aidata ära hoida võimalikke probleeme. Samuti on äärmiselt oluline, et õpetajatel oleks koolis olemas tugivõrgustik, kellelt saada juhtunuga hakkamasaamiseks emotsionaalset tuge. Seega tasuks igal koolil kaaluda, kas nad propageerivad õpetajate seas näiteks pöördumist koolipsühholoogi või õppenõustajate poole. Isegi kui formaalselt on koolil olemas ametilt inimene, kes võiks õpetajatele psühholoogilist tuge pakkuda, tuleks arvestada sellega, et kõik isiksused ei sobitu omavahel ning iga õpetaja ei soovi koolisiseste osalistega muret jagada. Seetõttu oleks vaja tagada võimalused, kus õpetaja saaks vajaduse korral abi leida ka väljaspool kooli.

Õpetajate küberkiusamise uurimisega on Eestis siiani veel üsna vähe tegeletud (vt Paal, 2014; Sule, 2019; Tikk, 2017; Välimaa, 2016), mistõttu on samasisuliste uuringute tegemine kindlasti vajalik, et saada laiem ülevaade õpetajate küberkiusamise kogemustest ja nähtust süvitsi mõista. Samas peab siinse artikli puhul silmas pidama, et kajastatud tulemused ei võimalda uuringu väikese valimi $(\mathrm{N}=14)$ tõttu tulemusi üldistada ega laiendada kogu Eesti õpetajaskonnale. Siinse uuringu valimi koostamisel polnud muu hulgas määratletud tingimust, et küberkiusamise kogemus peab olema korduv, nagu seda on küberkiusamise defineerimisel olulise karakteristikuna esile toodud (vt Smith et al., 2008). Jätku-uuringutes võiks seega kaaluda veelgi konkreetsemate kriteeriumide kehtestamist, mis võimaldaksid vajaduse korral eristada ühekordset küberkiusamist järjepidevast küberkiusamisest. 
Hoolimata eeltoodud piirangutest annavad uuringu tulemused siiski väärtusliku sisendi mõistmaks, milliste õpilastepoolse küberkiusamise liikidega õpetajad kokku puutuda võivad. Samuti annavad uuringu tulemused ainest praktilisteks ettepanekuteks koolidele, kuidas õpetaja vastu suunatud küberkiusamise juhtumitega tegeleda. Kuna pea kõik uuringus osalenud õpetajad olid teadlikud kolleegi või mõne teise kooli õpetaja õpilasepoolsest küberkiusamise juhtumist, on soovitatav seda teemat edasi uurida kvantitatiivselt, et saada aimu probleemi ulatusest. Samuti pole seni ülevaadet, kui paljud haridusasutused on rakendanud küberkiusamise valdkonnas mingeid regulatsioone ja juhiseid. Seega võiksid tulevased uuringud selgitada välja meetmeid, mida on seni koolides õpetaja (küber)kiusamise ennetamiseks ja juhtumite lahendamiseks ette võetud. Lisaks tuleks uurida, milliseid samme on riiklikul tasandil ette võetud selleks, et ennetada ja vähendada õpetajate küberkiusamise ohvriks langemist.

\section{Tänusõnad}

Täname kõiki uuringus osalenud õpetajaid ning kaasatud inimesi ja organisatsioone, kes panustasid nõu ja jõuga uuringu valmimisse.

\section{Kasutatud kirjandus}

Asterhan, C. S. C., \& Rosenberg, H. (2015). The promise, reality and dilemmas of secondary school teacher-student interactions on Facebook: the teacher perspective. Computers \& Education, 85, 134-148. https://doi.org/10.1016/j.compedu.2015.02.003

Atay, A. (2009). Facebooking the student-teacher relationship: How Facebook is changing student-teacher relationships. Rocky Mountain Communication Review, $6,71-74$.

Bauman, S. (2014). Cyberbullying: What counselors need to know. Hoboken: John Wiley \& Sons.

Daniels, J. A., Bradley, M. C., \& Hays, M. (2007). The impact of school violence on school personnel: Implications for psychologists. Professional Psychology: Research and Practice, 38(6), 652-659. https://doi.org/10.1037/0735-7028.38.6.652

Davenport, P. (2014). Educators' perspectives on having been cyber harassed: A phenomenological study. Doctoral dissertation, Liberty University.

Eden, S., Heiman, T., \& Olenik-Shemesh, D. (2013). Teachers' perceptions, beliefs and concerns about cyberbullying. British Journal of Educational Technology, 44(6), 1036-1052._https://doi.org/10.1111/j.1467-8535.2012.01363.x

Gunnulfsen, A. E. (2016). School leadership and the knowledge of teacher-student interaction on Facebook: A study of a lower secondary school in Norway. International Journal of Social Media and Interactive Learning Environments, 4(2), 169-186. 
Jürisaar, K. (2019). Õpetajate küberkiusamine õpilaste poolt: kiusatute tõlgendused ja kogemused. Margistritöö. Tartu Ülikool, ühiskonnateaduste instituut.

Kalmus, V., Masso, A., \& Linno, M. (2015). Kvalitatiivne sisuanalüüs. Sotsiaalse analüüsi meetodite ja metodoloogia õpibaas. Tartu Ülikool. Külastatud aadressil http://samm.ut.ee/kvalitatiivne-sisuanalyys

Kauppi, T., \& Pörhölä, M. (2012). School teachers bullied by their students: Teachers' attributions and how they share their experiences. Teaching and Teacher Education, 28(7), 1059-1068. https://doi.org/10.1016/j.tate.2012.05.009

Keasberry, C. (2018). Social Media, teacher-student relationships, and student learning. International Journal for Educational Media and Technology, 12(2), 27-34.

Kopecký, K., \& Szotkowski, R. (2017a). Specifics of Cyberbullying of Teachers in Czech Schools - A National Research. Informatics in Education, 16(1), 103-120. https://doi.org/10.15388/infedu.2017.06

Kopecký, K., \& Szotkowski, R. (2017b). Cyberbullying, cyber aggression and their impact on the victim - The teacher. Telematics and Informatics, 34(2), 506-517. https://doi.org/10.1016/j.tele.2016.08.014

Kyriacou, C., \& Zuin, A. (2016). Cyberbullying of teachers by students on YouTube: Challenging the image of teacher authority in the digital age. Research Papers in Education, 31(3), 255-273. https://doi.org/10.1080/02671522.2015.1037337

Kyriacou, C. (2001). Teacher Stress: Directions for future research. Educational Review, 53(1), 27-35. https://doi.org/10.1080/00131910120033628

Laherand, M.-L. (2008). Kvalitatiivne uurimisviis. Tallinn: Infotrükk.

Marwick, A., \& boyd, d. (2014) 'It's just drama': Teen perspectives on conflict and aggression in a networked era. Journal of Youth Studies, 17(9), 1187-1204. https://doi.org/10.1080/13676261.2014.901493

Menesini, E., \& Nocentini, A. (2009). Cyberbullying definition and measurement: Some critical considerations. Zeitschrift Für Psychologie/Journal of Psychology, 217(4), 230-232._https://doi.org/10.1027/0044-3409.217.4.230

Naruskov, K., \& Luik, P. (2015). Küberkiusamise fenomeni tajumine Eesti õpilaste seas: sooline võrdlus kiusamise kriteeriumite ja liikide alusel. Eesti Haridusteaduste Ajakiri, 3(2), 186-215. https://doi.org/10.12697/eha.2015.3.2.07

Naruskov, K. (2020). The Perception of Cyberbullying among Estonian Students According to Cyberbullying Types and Criteria. Doktoritöö, Tartu Ülikool.

Nocentini, A., Calmaestra, J., Schultze-Krumbholz, A., Scheithauer, H., Ortega, R., \& Menesini, E. (2010). Cyberbullying: Labels, behaviours and definition in three European countries. Australian Journal of Guidance and Counselling, 20(2), 129142. https://doi.org/10.1375/ajgc.20.2.129

Ontario College of Teachers (2007). State of the Teaching Profession 2007. Full Report on Province-Wide Survey. Canada: COMPAS Inc. Külastatud aadressil https://www.oct.ca/ /media/F1A8E6DBFE63478FB68B170AEA653287.ashx

Paal, D. (2014). Küberkiusamise levik õpetajate seas Tartumaa ja Viljandimaa õpetajate hinnangul. Magistritöö. Tartu Ülikool, sotsiaal- ja haridusteaduskond.

Phippen, A. (2011). The online abuse of professionals - Research report from the UK Safer Internet Centre. South West Grid for Learning Trust. Külastatud aadressil https://static.lgfl.net/LgflNet/downloads/online-safety/LGfL-OS-ResearchArchive-2011-SWGfL-Online-Abuse-of-Professionals.pdf 
Rao, T. S., Bansal, D., \& Chandran, S. (2018). Cyberbullying: A virtual offense with real consequences. Indian Journal of Psychiatry, 60(1), 3-5.

https://doi.org/10.4103/psychiatry.IndianJPsychiatry_147_18

Salmons, J. (2010). Online Interviews in Real Time. Thousand Oaks: Sage Publications.

Saveljev, K. (2017). Õpetajatele suunatud vägivald Pärnumaa üldhariduskoolide näitel. Rakenduskõrghariduse lõputöö. Tartu Ülikool.

Smith, P. K., Mahdavi, J., Carvalho, M., Fisher, S., Russell, S., \& Tippett, N. (2008). Cyberbullying: Its nature and impact in secondary school pupils. Journal of Child Psychology and Psychiatry, 49(4), 376-385. https://doi.org/10.1111/j.1469-7610.2007.01846.x

Sule, K. (2019). Õpetajate arusaamad ópilastepoolse kiusamise kohta. Bakalaureusetöö, Tartu Ülikool.

Žardeckaitè-Matulaitienè, K., \& Paluckaitè, U. (2013). The relation between teacher's self- disclosure and student's motivation to learn. European Scientific Journal, 9, 1857-7881.

The National Association of Schoolmasters Union of Women Teachers (NASUWT) (2013). The abuse of social media and internet sites - A survey of teachers' experiences. Külastatud aadressil http://download.eiie.org/Docs/WebDepot/NASUWT_ Theabuseofsocialmediaandinternetsites.pdf

Tikk, S. (2017). Õpetajate kiusamine ópilaste poolt põhikoolide õpetajate näitel. Magistritöö. Tartu Ülikool.

Vaillancourt, T., Faris, R., \& Mishna, F. (2017). Cyberbullying in children and youth: Implications for health and clinical practice. Canadian Journal of Psychiatry. Revue Canadienne de Psychiatrie, 62(6), 368-373.

https://doi.org/10.1177/0706743716684791

Välimaa, M. (2016). Õpetajate poolt kogetud kiusamine ning võimalikud lahendused selle vähendamiseks. Bakalaureusetöö. Tartu Ülikool.

Willard, N. (2007). Educator's guide to cyberbullying and cyberthreats: Responding to the challenge of online social aggression, threats, and distress. Illinois: Research Press.

Özkilic, R., \& Kartal, H. (2012). Teachers bullied by their students: How their classes influenced after being bullied? Procedia - Social and Behavioral Sciences, 46, 3435-3439. https://doi.org/10.1016/j.sbspro.2012.06.080 


\title{
Teacher cyberbullying and possible interventions at school: a view of teachers experiencing student cyberbullying
}

\author{
Kätlyn Jürisaar ${ }^{a 1}$, Andra Siibak ${ }^{a}$ \\ ${ }^{a}$ Institute of Social Studies, University of Tartu
}

\begin{abstract}
Summary
Research indicates that teacher-student interaction on social media may have a positive effect on teacher-student relationships, as well as on students' study results and their motivation to learn (Keasberry, 2018). However, digitally mediated communication can also have its downsides, as misuse of technology and information may result in teachers falling victim to cyberbullying by students (Kyriacou \& Zuin, 2016; Phippen, 2011). According to Smith et al. (2008), cyberbullying is an aggressive and intentional act directed repeatedly against one or more persons, and for a long time through electronic means (e-mail, text messaging, social media platforms or chat rooms, etc.).

Previous research (Kopecký \& Szotkowski, 2017a; NASUWT, 2013; Phippen, 2011) indicates that a significant number of teachers have been exposed to cyberbullying. For example, in an empirical study conducted in the UK ( $\mathrm{N}=377)$, almost $36 \%$ of the educational professionals (i.e. teachers, management, support staff) surveyed were either cyberbullied themselves or aware of some of their colleagues' incidents (Phippen, 2011, p. 9). Scholars (Willard, 2007; Kopecký \& Szotkowski, 2017b) propose that teachers can fall victim to many different forms of cyberbullying (e.g. flaming, sharing of degrading visuals, cyberstalking, harassment, denigration, etc.). Although efforts have been made to draw attention to the seriousness of the problem (Kyriacou \& Zuin, 2016, p. 259; Eden, Heiman, \& Olenik-Shemesh, 2013, p. 1040) and potential severe consequences to the teacher's career and private life (Kopecký \& Szotkowski, 2017b; Davenport, 2014; NASUWT, 2013), there is still relatively little empirical research that has focused primarily on teacher cyberbullying by students. Although several quantitative studies have been carried out (cf. Kopecký \& Szotkowski, 2017b; NASUWT, 2013; Ontario College of Teachers, 2007; Phippen, 2011), the number of qualitative studies is still scarce (see
\end{abstract}

Institute of Social Studies, University of Tartu, Lossi 36, Tartu, 51003 Estonia; katlyn.jyrisaar@gmail.com 
Kyriacou \& Zuin, 2016). Despite the fact that there have been references to the existence of the problem in several student theses (Paal, 2014; Sule, 2019; Tikk, 2017; Välimaa, 2016), cyberbullying of teachers by their students has not yet triggered academic attention in Estonia.

The aim of the present study is to analyse the opinions and experiences of teachers of Estonian general education schools $(\mathrm{N}=14)$ who have experienced cyberbullying by students and to investigate what kind of school intervention opportunities teachers recommend to solve cases of cyberbullying. The following two key research questions were formulated:

1) What forms of cyberbullying by their students have the teachers encountered?

2) How could the school intervene in cyberbullying cases of teachers?

Considering that teachers' cyberbullying is a sensitive and hidden topic and recruiting to the study therefore more difficult, snowball sampling which is considered suitable for recruiting hard-to-reach groups (Salmons, 2010), was used. To find the informants, active cooperation with the Estonian Teachers' Union and the Bullying Free School Foundation was established. To reach more people, a video was published on Facebook on January 3, 2019, inviting teachers with student initiated cyberbullying experiences to participate in the study. The video was shared 267 times and viewed 31,000 times (Jürisaar, 2019).

In spring 2019 semi-structured individual interviews with Estonian teachers $(\mathrm{N}=14)$ who had been cyberbullied by their students were carried out. The sample included individuals who had worked as a teacher up to five years $(\mathrm{N}=6)$ as well as those, whose career was longer than fourteen years $(\mathrm{N}=8)$. Each of the interviewees was able to choose the best time, format and place for the interviews. All in all, we conducted 10 individual face-to-face interviews, two telephone interviews and two video calls via the internet (Skype, Facebook).

The transcriptions (419 pages) were analysed using a qualitative content analysis, as this method provides an overview of the text being studied as a whole and focuses on the main and important meanings of the text, while also supporting hidden-line analysis (Kalmus, Masso, \& Linno, 2015).

Relying on the cyberbullying classifications developed by Willard (2007), and Kopecký and Szotkowski (2017b), our findings indicated that participating teachers had experienced the following six forms of cyberbullying: 1) sharing degrading visual material depicting teachers (e.g. processed photographs); 2) flaming; 3) denigration; 4) harassment; 5) impersonation (e.g. identity theft) and 6) cyberstalking. In addition to sharing their immediate experience, almost all the teachers who participated in the study were able to talk about the cyberbullying incident of a colleague or teacher from another school. 
Similar to the findings of other studies (Kopecký \& Szotkowski, 2017b; NASUWT, 2013; Phippen, 2011), our interviews revealed that the greatest number of teachers in our sample had been cyberbullied by sharing degrading visuals (e.g. processed photos). On these occasions a photograph of the teacher was downloaded either from the internet, or a photo was taken of the teacher in the classroom or in some public place. Vulgar additions are added to the photo and then distributed publicly, either on the student's social media account, the Instagram account of school memes, or via social media groups.

Teachers in our sample had also often experienced flaming, i.e. students had sent hostile, vulgar and insulting messages (e.g. in Facebook Messenger) or e-mails either under their own name or anonymously and denigration i.e. students had posted cruel rumours, gossip and derogatory comments about the teachers on different web platforms. One of the interviewees was a victim of a long-term online harassment by students; while another had fallen victim to impersonation i.e. students made a fake Facebook account of the teacher and posted problematic content under her name. One teacher in our sample had also experienced cyberstalking by a student.

Our interviews indicate that schools play a significant role in preventing and combating cyberbullying of teachers. Similarly to the Kopecký and Szotkowski's (2017b) study, our interviewees emphasised that schools need to support and protect the teacher when dealing with the incident (e.g. representing the teacher in dealing with parents, talking to the bully) and should have zero tolerance for any negative behaviour directed at teachers. Teachers considered it important that school regulations should provide the necessary measures to protect and support teachers in dealing with cyberbullying (rules of procedure, guidelines, etc.). Similar to the teachers in our study, Kopecký \& Szotkowski (2017b) also recommend developing both preventive programmes as well as a crisis plan to prevent and solve cyberbullying of teachers.

According to the teachers in our sample, there is also a need to increase general awareness and knowledge of the school professionals about teachers' cyberbullying. For example, it was considered important that training, teaching materials, and programmes were provided, to be better able to detect, address and prevent cyberbullying in the future. Furthermore, similar to the teachers who have experienced bullying (see Daniels, Bradley, \& Hays, 2007; Özkilic \& Kartal, 2012), teachers in our sample also believed it to be important to provide cyberbullied teachers with both psychological and technical support (e.g. by educational technologist) when dealing with the incident (e.g. help the teachers to remove student-posted material from the web).

The study provides a novel input in assessing what forms of student initiated cyberbullying Estonian teachers have experienced, as well as practical 
recommendations for possible methods for interventions in schools. Still, as the findings are based on a relatively small sample $(\mathrm{N}=14)$, the results cannot be generalised or extended to the entire Estonian teaching community. Furthermore, even though researchers (Smith et al., 2008) consider repetition as an important criterion in defining cyberbullying, there was no defined condition for the sample of this study that the cyberbullying experience must be a recurring case. Hence, future studies should consider setting more specific criteria for the sample and distinguishing one-time cyberbullying from consistent cyberbullying.

In order to get a better idea of the magnitude of the problem, future studies should explore the topic quantitatively. There is also currently no overview of how many educational institutions have implemented any regulations and guidelines on the topic of cyberbullying. Thus, future research could also chart the measures taken so far to prevent and deal with cyberbullying of teachers in schools.

Keywords: cyberbullying, cyberbullying of teachers, electronic bullying, cyberbullying interventions, school, intervention measures, students 